\title{
PENGARUH SUBTITUSI JAGUNG DENGAN TEPUNG BIJI ALPUKAT TERHADAP KONSUMSI RANSUM, ASUPAN PROTEIN, DAN RETENSI NITROGEN PADA AYAM BROILER
}

(The Effect of Dietary Corn Subtitution to Avocado Seed Meal in the Ration on Feed Consumption, Protein Intake, And Nitrogen Retention in Broiler Chicken)

\author{
S. Irianing ${ }^{1}$, N. Suthama ${ }^{2}$ dan I. Mangisah ${ }^{3}$ \\ 1) Mahasiswa Pasca Sarjana Fakultas Peternakan Dan Pertanian Universitas Diponegoro \\ Kampus drh. Soejono Koesoemowardojo Tembalang Semarang 50275 \\ E-mail : Irianing achmad@yahoo.com \\ ${ }^{2,3)}$ Staf pengajar Fakultas Peternakan dan Pertanian, Universitas Diponegoro \\ Kampus drh. R. Soejono Kusumowardojo Tembalang, Semarang 50275
}

Diterima : 15 Desember 2014 Disetujui : 25 November 2015

\begin{abstract}
This research aimed to clarify the effect of dietary corn subtitution to avocado seed meal in the ration on feed consumption, protein intake, and nitrogen retention in broiler chicken. 90 of day old chick (DOC) Lohmann strain broiler chickens with an average of initial body weight of 41,38 $\pm 1,08 \mathrm{~g}$ were used in this research. The subjects were divided based on completely randomized design (CRD) to 3 different feeding treatments, consisted of TO (control ration), T1 (ration with 7,5\% avocado seed meal), and T2 (ration with 15\% avocado seed meal). The parameter of observed were feed consumption, protein intake, and nitrogen retention. This result that feeding avocado seed meal significantly effected $(P<0,05)$ on feed consumption, protein intake, and nitrogen retention. In conclusion was that increase of feeding avocado seed meal until 15\% decrease effect on feed intake, protein intake, and nitrogen retention in broiler chicken.
\end{abstract}

Keyword : broiler chicken, feed intake, protein intake, and nitrogen retention.

\begin{abstract}
ABSTRAK
Penelitian bertujuan mengetahui dan mengkaji pengaruh penggunaan tepung biji alpukat terolah sebagai subtitusi jagung dalam ransum terhadap konsumsi ransum, asupan protein dan retensi nitrogen pada ayam broiler. Materi yang digunakan adalah 90 ekor day old chick (DOC) unsex strain Lohmann dengan bobot badan awal rata-rata 41,38 $1,08 \mathrm{~g}$. Rancangan percobaan yang digunakan adalah Rancangan Acak Lengkap (RAL) dengan 3 perlakuan dan 5 ulangan. Ransum perlakuan meliputi T0 = ransum kontrol (tanpa tepung biji alpukat), $\mathrm{T} 1=$ ransum dengan $7,5 \%$ tepung biji alpukat, $\mathrm{T} 2=$ ransum dengan $15 \%$ tepung biji alpukat. Parameter yang diamati adalah konsumsi ransum, asupan protein dan retensi nitrogen. Hasil penelitian menunjukkan bahwa terdapat pengaruh yang nyata $(p<0,05)$ tepung biji alpukat terhadap konsumsi ransum, asupan protein dan retensi nitrogen. Simpulan penelitian adalah peningkatan level penggunaan tepung biji alpukat sampai $15 \%$ sebagai subtitusi jagung dalam ransum ayam broiler menurunkan konsumsi ransum, asupan protein dan retensi nitrogen.
\end{abstract}

Kata kunci: broiler, konsumsi ransum, asupan protein, retensi nitrogen 


\section{PENDAHULUAN}

Ketersediaan jagung sebagai bahan penyusun ransum ternak unggas masih bersaing dengan kebutuhan manusia. Selain harganya yang semakin mahal, ketersediaan jagung di Indonesia sebagian masih impor. Oleh karena itu, untuk menekan biaya produksi perlu bahan pakan sumber energi alternatif yaitu biji alpukat. Biji alpukat merupakan limbah dari buah alpukat adalah bahan alternatif yang dapat dimanfaatkan sebagai pakan ternak sumber energi untuk subtitusi jagung. Persentase biji dalam buah alpukat sebesar 10-15\%. Produksi buah alpukat di Indonesia pada tahun 2013 mencapai 276.311 ton, sehingga dapat dihitung produksi limbah biji alpukat mencapai 34.538 ton (Badan Pusat Statistik, 2013).

Pemanfaatan biji alpukat diharapkan dapat mengurangi penggunaan jagung sehingga biaya pakan menjadi murah. Biji alpukat mengandung protein kasar 10,40\% dan energi metabolis $3570 \mathrm{kkal} / \mathrm{kg}$, tetapi pemakaiannya harus dibatasi karena mengandung zat anti nutrisi berupa tanin sebesar 1,02\% (Nelwida, 2009). Tanin yang membentuk senyawa komplek dengan ikatan peptida dari protein, tidak larut di dalam saluran pencernaan sehingga dapat mempengaruhi ketersediaan protein. Oleh karena itu, perlu pengolahan sebelum biji alpukat dipakai sebagai komponen ransum melalui perendaman dengan larutan kalsium hidroksida $\mathrm{Ca}(\mathrm{OH})_{2}$ dan perebusan dengan air panas.Penurunan kadar tanin sebagai anti nutrisi yang dilakukan pada biji alpukat diharapkan tidak mengganggu pencernaan nutrien khususnya protein, sehingga dampak positif pada produktivitas ayam broiler. Tujuan penelitian adalah untuk mengetahui dan mengkaji pengaruh penggunaan tepung biji alpukat terolah sebagai subtitusi jagung terhadap asupan protein, retensi $\mathrm{N}$ dan presentase karkas pada ayam broiler. Manfaat penelitian adalah memberikan informasi tentang penggunaan tepung biji alpukat terolah sebagai substitusi jagung yang tidak mengganggu produktivitas ayam broiler berdasarkan pemanfaatan protein.

\section{MATERI DAN METODE}

\section{Materi}

Materi yang digunakan adalah 90 ekor DOC unsex strain Lohmann dengan bobot awal rata-rata 41,38 $\pm 1,08$ g. Komposisi dan kandungan nutrisi dalam ransum penelitian dapat dilihat pada Tabel 1. Perlengkapan yang digunakan adalah peralatan kandang, timbangan, dan termometer.

\section{Metode}

Penelitian dimulai dengan tahap persiapan teknis meliputi persiapan kandang, pembuatan tepung biji alpukat, penyusunan ransum serta persiapan ternak dan peralatan yang digunakan pada penelitian. Pembuatan tepung biji alpukat dengan mengiris tipis biji alpukat dengan pisau, kemudian merendam biji alpukat dengan larutan kalsium hidroksida $\mathrm{Ca}(\mathrm{OH})_{2}$ dengan perbandingan $200 \mathrm{~g} \mathrm{Ca}(\mathrm{OH})_{2}$ dan 1 liter air selama 30 menit. Biji alpukat yang sudah direndam, kemudian dibilas dengan air hingga bersih, selanjutnya merebus biji alpukat dengan air mendidih selama 30 menit. Biji alpukat yang sudah direbus, dikeringkan dibawah sinar matahari sampai kering. Proses selanjutnya menggiling biji alpukat sampai halus menjadi tepung. 
Tabel 1. Komposisi dan Kandungan Nutrisi Ransum Penelitian

\begin{tabular}{|c|c|c|c|}
\hline Bahan pakan & T0 & T1 & $\mathrm{T} 2$ \\
\hline & \multicolumn{3}{|c|}{-------------(\%)------------- } \\
\hline Jagung kuning & 59,00 & 51,50 & 44,00 \\
\hline Tepung biji alpukat & - & 7,50 & 15,00 \\
\hline Bungkil kedelai & 15,00 & 15,00 & 15,00 \\
\hline Bekatul & 12,00 & 12,00 & 12,00 \\
\hline PMM & 8,00 & 8,00 & 8,00 \\
\hline Tepung ikan & 5,00 & 5,00 & 5,00 \\
\hline Premix & 1,00 & 1,00 & 1,00 \\
\hline Jumlah & $\overline{100}$ & $\overline{100}$ & $\overline{100}$ \\
\hline \multicolumn{4}{|l|}{ Kandungan nutrien $(\%)^{*}$} \\
\hline Protein kasar $^{*_{a}}$ & 20,06 & 20,20 & 20,33 \\
\hline Energi Metabolis $(\mathrm{kkal} / \mathrm{kg})^{\mathrm{a}}$ & $3.079,00$ & $3.105,00$ & $3.132,00$ \\
\hline Lemak kasar *a & 6,34 & 6,43 & 6,52 \\
\hline Serat kasar ${ }^{* b}$ & 5,12 & 5,24 & 5,67 \\
\hline Kalsium $^{* a}$ & 0,88 & 0,93 & 0,98 \\
\hline Fosfor $^{* a}$ & 0,55 & 0,54 & 0,54 \\
\hline Tanin $^{* a}$ & 0,27 & 0,32 & 0,39 \\
\hline
\end{tabular}

Keterangan :

a Dianalisis di Lab. Ilmu Nutrisi dan Pakan Fakultas Peternakan dan Pertanian Universitas Diponegoro, Semarang.

b Dianalisis di Pusat Studi Pangan dan Gizi Universitas Gadjah Mada, Yogyakarta.

Tahap pendahuluan, dilakukan vaksinasi ND melalui tetes mata pada umur 4 hari. $D O C$ hingga umur 10 hari diberi $100 \%$ ransum komersial, umur 11-13 hari dilakukan adaptasi pakan untuk digantikan menjadi ransum kontrol, umur 14 hari diberi $100 \%$ ransum kontrol, sedangkan pada umur 15-41 hari diberi ransum perlakuan dan dipindahkan dalam kandang petak. Ransum perlakuan diberikan ad libitum setiap hari selama pemeliharaan. Data yang diamati meliputi konsumsi ransum, asupan protein, dan retensi nitrogen.

\section{HASIL DAN PEMBAHASAN}

Hasil pengukuran terhadap konsumsi ransum, asupan protein dan retensi nitrogen ditampilkan pada Tabel 2. Pengaruh level penggunaan tepung bii alpukat terolah sebagai subtitusi jagung dalam ransum menunjukkan perbedaan yang nyata $(\mathrm{p}<0,05)$ menurunkan konsumsi ransum, asupan protein dan retensi nitrogen.

Konsumsi ransum selama penelitian (15-41 hari) menunjukkan bahwa peningkatan penggunaan tepung biji alpukat terolah (T1 dan $\mathrm{T} 2)$ nyata $(\mathrm{p}<0,05)$ dibandingkan ransum kontrol (T0) (Tabel 2). Konsumsi ransum mengalami penurunan seiring dengan peningkatan level penggunaan tepung biji alpukat terolah.

Fenomena tersebut dapat diasumsikan bahwa akibat pengaruh warna ransum perlakuan karena semakin tinggi penggunaan tepung biji alpukat terolah, warna ransum menjadi semakin gelap. Warna ransum bagi ternak unggas mempengaruhi selera makan atau palatabilitas. Palatabilitas ransum unggas tidak berdasarkan penciuman dan melalui lidah, karena bau dan rasa ransum bukan penentu selera makan pada unggas. Selera makan unggas ditentukan oleh terang atau gelapnya warna ransum. Menurut 
Sulistyoningsih (2009) warna adalah aspek utama dari cahaya, melalui retina mata diteruskan oleh syaraf mata menuju hipotalamus anterior, mensekresikan hormon yang berfungsi mempengaruhi enzim yang berhubungan dengan proses metabolisme dan meningkatkan aktiftas metabolisme.

Tabel 2. Rata-rata konsumsi ransum, asupan protein dan retensi nitrogen ayam broiler

\begin{tabular}{lccc}
\hline \hline \multirow{1}{*}{ Parameter } & \multicolumn{3}{c}{ Perlakuan } \\
\cline { 2 - 4 } & $\mathrm{T} 0$ & $\mathrm{~T} 1$ & $\mathrm{~T} 2$ \\
\hline & $\ldots \ldots \ldots \ldots \ldots \ldots \ldots \ldots \ldots \ldots \ldots \ldots \ldots \ldots \ldots \ldots \ldots \ldots \ldots \ldots \ldots \ldots \ldots \ldots \ldots \ldots \ldots \ldots \ldots \ldots \ldots \ldots \ldots \ldots \ldots \ldots \ldots \ldots \ldots \ldots \ldots \ldots \ldots \ldots \ldots \ldots \ldots \ldots \ldots \ldots \ldots \ldots \ldots \ldots \ldots \ldots$ \\
Konsumsi ransum & $105,05^{\mathrm{a}}$ & $86,74^{\mathrm{ab}}$ & $80,08^{\mathrm{b}}$ \\
Asupan protein & $15,83^{\mathrm{a}}$ & $12,46^{\mathrm{b}}$ & $11,03^{\mathrm{b}}$ \\
Retensi nitrogen & $3,35^{\mathrm{a}}$ & $2,0^{\mathrm{b}}$ & $1,54^{\mathrm{b}}$ \\
\hline
\end{tabular}

Keterangan : Huruf berbeda pada nilai rata-rata menunjukkan perbedaan nyata $(\mathrm{P}<0,05)$.

Retnani et al. (2009) memperkuat proses tersebut diatas bahwa ayam lebih menyenangi warna orangye kuning dan warna yang mengkilap yang dapat merangsang perhatian. Hal lain yang mempengaruhi menurunnya konsumsi ransum dapat diasumsikan sebagai akibat adanya kandungan tanin dalam ransum. Kandungan tanin ransum semakin meningkat seiring dengan semakin meningkatnya penggunaan tepung biji alpukat terolah dalam ransum sehingga dapat mempengaruhi penurunan konsumsi ransum. Hal tersebut sesuai dengan hasil penelitian Akmal (2008) dan Anita et al. (2012) bahwa semakin banyak kandungan tanin dalam ransum dapat menurunkan konsumsi ransum pada ayam broiler. Tanin merupakan satu jenis antinutrisi yang terdapat pada bahan pakan secara alami. Antinutrisi tersebut dapat membatasi konsumsi ransum pada ternak unggas karena dapat mengganggu proses pencernaan ransum di dalam usus akhirnya berakibat pada umpan balik terhadap konsumsi.

Demikian pula Nilai asupan protein nyata menurun karena dihitung dari nilai daya cerna protein ransum dikalikan dengan konsumsi protein. Nilai konsumsi protein signifikan menurun dalam penelitian ini, sehingga hal tersebut selaras dengan hasil asupan protein yang nyata menurun. Asupan protein dalam tubuh ternak unggas dipengaruhi oleh jumlah konsumsi ransum dan konsumsi protein. Konsumsi protein semakin menurun akibat semakin meningkatnya penggunaan tepung biji alpukat. Kondisi ini sesuai dengan pendapat Permana (2012) bahwa asupan protein dipengaruhi oleh jumlah konsumsi ransum dan protein. Demikian pula Gultom et al. (2014) menyatakan bahwa konsumsi ransum berhubungan dengan konsumsi protein, apabila konsumsi protein tinggi menyebabkan asupan protein juga tinggi. Penurunan asupan protein juga dapat dikaitkan dengan adanya tanin di dalam ransum karena biji alpukat mengandung tanin (Tabel 2). Tanin bersifat dapat membentuk senyawa komplek dengan ikatan peptida dari protein, tidak larut dalam saluran pencernaan, dan segera dikeluarkan melalui ekskreta sehingga mempengaruhi ketersediaan protein. Menurut Akmal (2008) tanin mempunyai kemampuan mengendapkan protein, karena tanin mengandung sejumlah kelompok fungsional ikatan yang kuat dengan molekul protein dan menghasilkan ikatan silang yang besar dan kompleks dalam bentuk protein tanin. Tanin menyebabkan daya cerna asam asam amino menurun yang seharusnya dapat diserap oleh 
villi usus yang dimanfaatkan untuk perkembangan jaringan tubuh ternak unggas.

Selanjutnya, retensi nitrogen erat kaitannya dengan asupan protein karena dipengaruhi oleh jumlah protein ransum yang dikonsumsi. Berdasarkan hasil analisis ragam penggunaan tepung biji alpukat terolah dalam ransum ayam broiler menunjukkan adanya pengaruh nyata terhadap retensi nitrogen $(p<0,05)$. Hasil uji Duncan menunjukkan bahwa peningkatan level penggunaan tepung biji alpukat terolah dalam ransum ( $\mathrm{T} 1$ dan $\mathrm{T} 2)$ nyata $(\mathrm{p}<0,05)$ menurunkan retensi nitrogen dibandingkan dengan ransum kontrol (T0). Rendahnya nilai retensi nitrogen pada ayam broiler berkaitan dengan semakin menurunnya jumlah asupan protein akibat dari berkurangnya tingkat konsumsi ransum. Konsumsi nitrogen berbanding lurus dengan konsumsi protein ransum, apabila konsumsi nitrogen tinggi, maka retensi nitrogen yang dihasilkan juga tinggi. Sebaliknya apabila konsumsi nitrogen rendah maka retensi nitrogen yang dihasilkan juga rendah. Hal ini sesuai dengan pendapat Maulana (2008) bahwa tingkat retensi nitrogen bergantung pada konsumsi nitrogen. Demikian pula menurut Sofiati (2008) bahwa meningkatnya konsumsi nitrogen memberikan kesempatan untuk retensi nitrogen lebih tinggi.

Rendahnya retensi nitrogen juga dapat diakibatkan oleh keberadaan tanin dalam ransum. Berdasarkan hasil penelitian Nyachoti et al. (1996) bahwa semakin tinggi kadar tanin dalam ransum semakin rendah retensi nitrogen yang dihasilkan karena tanin mengikat protein menjadi senyawa yang tidak larut. Selanjutnya protein tersebut diekskresikan melalui ekskreta yang berakibat pada penurunan retensi nitrogen, sehingga tidak bermanfaat bagi inang (Bikrisima et al, 2014).

\section{KESIMPULAN}

\section{Kesimpulan}

Berdasarkan hasil penelitian dapat disimpulkan bahwa peningkatan level penggunaan tepung biji alpukat terolah sampai $15 \%$ sebagai subtitusi jagung dalam ransum ayam broiler, menurunkan konsumsi ransum, asupan protein, dan retensi nitrogen.

\section{Saran}

Perlu pengkajian yang lebih mendalam berkaitan dengan persentase penggunaan tepung biji alpukat sebagia subtitusi jagung dalam ransum ayam broiler.

\section{DAFTAR PUSTAKA}

Akmal. 2008. Pengaruh pemberian daun sengon (Albizzia falcataria) hasil rendaman dengan larutan $\mathrm{Ca}(\mathrm{OH})_{2}$ terhadap bobot karkas dan bobot organ pencernaan ayam pedaging. $J$. Ilmiah Ilmu - Ilmu Pet. 9 (4): 100 107.

Anita, W. Y., I. Astuti., Suharto. 2012. Pengaruh pemberian tepung daun teh tua dalam ransum terhadap performan dan persentase lemak abdominal ayam broiler. J. Trop. Anim. Husbandry. 1(1) : 1-6.

Badan Pusat Statistik. 2013. Produksi Buahbuahan dan Sayuran Tahunan di Indonesia. www.bps.go.id. Diakses tanggal 24 agustus 2014.

Bikrisima, S. H. L., L. D. Mahfudz., N. Suthama. 2014. Kemampuan produksi ayam broiler yang diberi tepung jambu biji merah sebagai 
sumber antioksidan alami. JITP. 3 (2): 69-75.

Gultom, S.M., Supratman, R.D.H., Abun., 2014. Pengaruh imbangan energi dan protein ransum terhadap bobot karkas dan bobot lemak abdominal ayam broiler umur $3-5$ minggu. Students e- Journal. 1(1) : 6 -10.

Maulana, Irfan. 2008. Nilai Retensi Nitrogen pada Ayam Kampung Umur 12 Minggu yang diberi Pakan Mengandung Tepung Silase Ikan. Skripsi. Fakultas Peternanakan Institut Pertanian Bogor, Bogor.

Nelwida. 2009. Efek Penggantian jagung dengan biji alpukat yang direndam air panas dalam ransum terhadap retensi bahan kering, bahan organik dan protein kasar pada ayam broiler. $J$. Ilmiah Ilmu-Ilmu Pet. 8 (1) : 50 -56.

Nyachoti, C. M., J. L. Atkinson and S. Leeson. 1996. Response of broiler chicks fed a high tannin sorghum diet. J. Appl. Poultry science. 239245.

Permana, Bintang Tampubolon. 2012. Pengaruh Imbangan Energi dan Protein Ransum Terhadap Energi Metabolis dan Retensi Nitrogen Ayam Broiler. Students $e-J o u r n a l$. 1(1) : $1-5$.

Retnani, Y., E. Suprapti., I. Firmansyah., L. Herawati., R. Mutia. 2009. Pengaruh penambahan zat pewarna dalam ransum ayam broiler terhadap penampilan, persentase berat bursa fabrisius, karkas dan organ dalam. $J$. Indon. Trop. Anim. Agric. 34 (2) : $115-121$.

Sofiati, E. A. M. R. 2008. Metabolisme Energi dan Retensi Nitrogen Broiler
Pasca Perlakuan Ransum Mengandung Tepung Daun Jarak Pagar (Jatropha curcas L.). Skripsi. Fakultas Peternakan Institut Pertanian Bogor, Bogor.

Sulistyoningsih, M. 2009. Pengaruh pencahayaan (lighting) terhadap performans dan konusumsi protein pada ayam. Prosiding Seminar Nasional ISBN 978 - 602-95207-0-5. Hal 1-20 